\title{
Illegitimate tasks of primary school teachers at selected schools in the Western Cape: A reality for a developing country?
}

\begin{tabular}{|c|c|}
\hline \multicolumn{2}{|c|}{$\begin{array}{l}\text { Authors: } \\
\text { Zahn van Niekerk }{ }^{1} \text { (]) } \\
\text { Susanna Goosen }{ }^{1} \text { (D) } \\
\text { Samantha P. Adams }{ }^{1} \text { (I) }\end{array}$} \\
\hline \multicolumn{2}{|c|}{$\begin{array}{l}\text { Affiliations: } \\
{ }^{1} \text { Department of Industrial } \\
\text { Psychology, Faculty of } \\
\text { Economic and Management } \\
\text { Sciences, Stellenbosch } \\
\text { University, Stellenbosch, } \\
\text { South Africa }\end{array}$} \\
\hline \multicolumn{2}{|c|}{$\begin{array}{l}\text { Corresponding author: } \\
\text { Zahn van Niekerk, } \\
\text { zgrobbelaar@gmail.com }\end{array}$} \\
\hline \multicolumn{2}{|c|}{$\begin{array}{l}\text { Dates: } \\
\text { Received: } 30 \text { June } 2020 \\
\text { Accepted: } 09 \text { Dec. } 2020 \\
\text { Published: } 30 \text { Mar. } 2021\end{array}$} \\
\hline \multicolumn{2}{|c|}{$\begin{array}{l}\text { How to cite this article: } \\
\text { Van Niekerk, Z., Goosen, S., \& } \\
\text { Adams, S.P. (2021). } \\
\text { Illegitimate tasks of primary } \\
\text { school teachers at selected } \\
\text { schools in the Western Cape: } \\
\text { A reality for a developing } \\
\text { country? SA Journal of } \\
\text { Industrial Psychology/SA } \\
\text { Tydskrif vir Bedryfsielkunde, } \\
47(0), \text { a1824. https://doi. } \\
\text { org/10.4102/sajip.v47i0.1824 }\end{array}$} \\
\hline \multicolumn{2}{|c|}{$\begin{array}{l}\text { Copyright: } \\
\text { (C) 2021. The Authors } \\
\text { Licensee: AOSIS. This } \\
\text { is licensed under the } \\
\text { Creative Commons } \\
\text { Attribution License. }\end{array}$} \\
\hline \multicolumn{2}{|l|}{ Read online: } \\
\hline 回的回 & $\begin{array}{l}\text { Scan this QR } \\
\text { code with your } \\
\text { smart phone or } \\
\text { mobile device } \\
\text { to read online. }\end{array}$ \\
\hline
\end{tabular}

Orientation: The quality of basic education in South Africa is in need of interventions to improve the general standard of education offered in many public schools. Teachers and their work experiences are important factors that impact this standard.

Research purpose: The aim of this study was to shed light on the factors that contribute to the experiences and outcomes of illegitimate tasks, as experienced by teachers, and the potential buffers to the negative effects of these tasks.

Motivation for the study: The motivation for this study was to inform human resource practices and interventions to enhance the work experiences of teachers.

Research approach/design and method: Exploratory qualitative research was conducted with 10 primary school teachers $(n=10)$ from a selected Western Cape education district. Responses to semi-structured individual interviews were transcribed verbatim, unedited and categorised into main themes through directed content analysis.

Main findings: Environmental and psychological factors that lead to the experience of unnecessary and unreasonable illegitimate tasks, the time-consuming nature and outcomes of these tasks, as well as mechanisms that can buffer the harmful effects of illegitimate tasks, were identified.

Practical/managerial implications: The identification of various contributing factors resulting in teachers' experience of different types of illegitimate tasks and associated outcomes. Potential interventions and recommendations for future research are made.

Contribution/value-addition: Qualitative studies regarding teachers' experience of illegitimate tasks in the South African context are lacking. This article sheds light on the contributing factors, unnecessary and unreasonable tasks experienced and outcomes, as well as mechanisms that buffer the effect of illegitimate tasks amongst primary school teachers.

Keywords: burnout; buffers to illegitimate tasks; contributing factors; employee engagement; illegitimate tasks; job demands-resources model; outcomes; primary school teachers; work experiences.

\section{Introduction}

In South Africa, there are numerous signs indicating that there is a crisis in education (Modisaotsile, 2012). Despite the report of the Department of Basic Education (DBE) that the annual pass rate of Grade 12 students improved from $78.20 \%$ in 2018 (2019, p. 2) to $81.30 \%$ in 2019 (2020, p. 6), of the 1171323 learners enrolled for Grade 1 in 2007 (DBE, 2009, p. 9), only 400761 passed the National Senior Certificate (NSC) examination in 2018 (DBE, 2019, p. 44). Similarly, 1122114 learners were enrolled for Grade 1 in 2008 (DBE, 2010, p. 11), but only 409906 of these students passed their NSC examination in 2019 (DBE, 2020, p. 7). These figures indicate that more than $50 \%$ of learners who enrolled for Grade 1 in 2007 and 2008, respectively, did not complete the Grade 12 NSC qualification in 2018 and 2019.

Furthermore, several cross-national assessments have also directed attention to challenges with the quality of primary and secondary education offered in many public schools across South Africa. The Global Competitiveness Report (GCR) of 2017-2018 ranked South Africa 116th in terms of the quality of primary and secondary education and 85th in terms of higher education and training out of 137 countries across the globe (World Economic Forum, 2018). 
Apart from poor academic achievement, other challenges facing the educational system in South Africa include teacher shortages and the general work ethic of teachers. According to Spaull (2013), South Africa is currently experiencing a shortage of qualified teachers. The Centre for Development and Enterprise estimated that 30000 teachers are needed over the next decade to meet the increased student enrolment rate (Hofmeyr \& Draper, 2015, p. 3). Many teachers are, however, leaving the teaching profession, despite retention strategies that have been implemented by the DBE (Mampane, 2012). Furthermore, work ethic and related behaviour such as arriving late and absenteeism are also widely recognised challenges amongst public school teachers (Taylor, 2008).

High turnover rates, arriving late and absenteeism amongst public school teachers could be regarded as symptoms of decreased employee engagement. Many teachers may choose to withdraw from their work, either physically or psychologically, in an attempt to cope with the job demands associated with their duties, tasks, working conditions and work experiences. Scriven (1994) explains that the duties which teachers have to perform differ from school to school, between different management regimes, at different times and between staff of differing seniority. The numerous duties which teachers have to perform, however significant or insignificant they may seem, should not be regarded as minor, as they require much effort from teachers to execute. It is our view that, oftentimes, teachers may be expected to perform tasks and duties, which could be regarded and classified as illegitimate tasks.

Illegitimate tasks are a relatively new construct in the field of industrial and organisational psychology and originate from the job demands-resources (JD-R) model (Semmer et al., 2015). Some studies have managed to shed light on the detrimental effects that illegitimate tasks can have on the well-being of employees in general. These effects range from job strain (Semmer et al., 2015), variance in employee health and behaviour (Eatough et al., 2016), high turnover intention (Apostel, Syrek, \& Antoni, 2018), unfavourable employee states at the end of the workday and a detachment from work (Sonnentag \& Lischetzke, 2018). The effects of illegitimate tasks could have numerous negative effects on the work experiences, well-being and performance of primary school teachers in South Africa. This, in turn, could affect the standard of basic education throughout the country. It is, therefore, important to explore the construct of illegitimate tasks in this setting.

\section{Research purpose and objectives}

The purpose of this article was to examine the work experiences, specifically regarding illegitimate task experiences of primary school teachers in the South African context, thereby illustrating the environmental and psychological factors that contribute to teachers' experience of illegitimate tasks and the outcomes thereof. Additionally, the results provide insight into the time-consuming nature of illegitimate tasks and mechanisms, which may buffer the negative effects of illegitimate tasks experienced by primary school teachers.

\section{Literature review Illegitimate tasks}

Illegitimate tasks are work tasks that do not form part of the core tasks associated with employees' occupation or professional identity and are thus not subjectively perceived as part of one's core role. These tasks therefore directly violate the rules and norms associated with employees' core tasks or responsibilities (Jacobshagen, 2006).

Adistinction is made between unnecessary tasks and unreasonable tasks, which collectively amount to illegitimate tasks. Unnecessary tasks refer to the lack of legitimacy and meaningfulness of tasks. Tasks are classified as unnecessary when: (1) the task should not have to be carried out at all, (2) the task does not make sense, (3) the task can be carried out with less effort if the organisation of work was more efficient, (4) the task can be carried out with less effort if others made fewer mistakes or (5) the task reflects supervisor preferences rather than necessities (Jacobshagen, 2006; Semmer et al., 2015).

Unreasonable tasks refer to tasks that are in violation of employees' occupational roles. These tasks may lead to a breach of the psychological contract between employees and their employers (Björk, Bejerot, Jacobshagen, \& Härenstam, 2013). Tasks are classified as unreasonable when: (1) the task is supposed to be carried out by someone else, (2) it falls outside employees' defined responsibilities, (3) it places the employee in an awkward position or (4) the task is perceived to be unfair (Jacobshagen, 2006).

It is important to note that the individual's subjective perception, as opposed to the objective evaluation of illegitimate tasks, might result in strain. Not all individuals will perceive or experience illegitimate tasks similarly. Individual and situational characteristics might play an important role in the perception of illegitimate tasks. For example, one individual may feel demeaned by a task, whilst another enjoys performing the same task. Therefore, the individual's perception of his or her work task should be considered when identifying illegitimate tasks (Jacobshagen, 2006).

\section{Outcomes of illegitimate tasks}

Illegitimate tasks impede individual performance when they create unreachable, unclear or conflicting demands. Failing to reach such performance standards threatens employees' ability to maintain a positive self-view. Moreover, illegitimate tasks also carry certain social messages. Work tasks may be perceived as normal in principle, but at the same time contain demeaning social messages under certain circumstances. In these circumstances, illegitimate tasks can send messages of disrespect, which pose a threat to employees' self-views (Semmer et al., 2015).

Jacobshagen (2006) suggests that illegitimate tasks may lead tojob strain and a deterioration in the well-being of employees. This was supported by Semmer et al. (2015) in their study on illegitimate tasks as a source of work stress, that is illegitimate 
tasks decreased employees' well-being and increased job strain. Eatough et al. (2016) found that illegitimate tasks predicted decreased employee self-esteem and job satisfaction, and increased anger and depressive moods. Moreover, significant associations between illegitimate tasks and unfavourable employee states (i.e. high negative affect and low self-esteem) at the end of the workday, detachment from work (Sonnentag \& Lischetzke, 2018) and higher turnover intentions (Apostel et al., 2018) have been reported.

It is evident that the outcomes of illegitimate tasks can have detrimental effects on employees' health and well-being. The current article argues that illegitimate tasks could signify a job demand within the parameters of the JD-R model (Demerouti, Bakker, Nachreiner, \& Schaufeli, 2001).

\section{The job demands-resource model}

The JD-R model classifies working conditions into two broad categories, job demands and job resources, and emphasises the interaction between job demands, job resources and personal resources. This interaction is postulated to lead to the development of job burnout (i.e. health impairment process) or employee engagement (i.e. motivational process).

Job demands refer to the physical, psychological, social or organisational aspects of a job that require sustained psychological and/or physical effort and skills (i.e. workload). These demands are associated with certain physiological and psychological costs that require physical and psychological efforts from employees. The literature distinguishes between challenging and hindrance job demands. The latter could become job stressors when continuous high levels of effort are required, without adequate recovery. They are undesirable constraints that interfere with an employee's ability to achieve work goals and potentially exhaust employees' physical and mental resources (Demerouti \& Bakker, 2011; Saks \& Gruman, 2014).

Job resources, on the other hand, are functional in achieving work goals, reducing job demands and stimulating learning, development and personal growth. Job resources can be located on an organisational level (e.g. job security and benefits) or an interpersonal and social level (e.g. team climate or social support). They can also be found in a specific job position (e.g. role clarity and decision-making) or in a task itself (e.g. task identity and autonomy). Job resources, as opposed to job demands, have the potential to increase employee engagement (Demerouti \& Bakker, 2011; Saks \& Gruman, 2014).

Job resources are necessary to deal with job demands. They activate a motivational process which may increase the level of employee engagement, positive attitudes and well-being. Personal resources are described as 'aspects of the self that are generally linked to resilience and refer to an individual's sense of their ability to control and impact their environment successfully' (Demerouti \& Bakker, 2011, p. 162). Personal resources are activated by job resources and are related to work engagement. It, additionally, acts as a mediating variable between job resources and employee engagement (Saks \& Gruman, 2014). Job resources and personal resources may, therefore, buffer the harmful impact of job demands on employees' well-being and contribute to high levels of employee motivation and engagement (Demerouti \& Bakker, 2011).

Within the framework of the JD-R, illegitimate tasks are classified as a job demand because illegitimate tasks require emotional and mental efforts that lead to negative affective reactions, emotional exhaustion, job burnout, irritability and lowered self-esteem (Demerouti et al., 2001). Considering the nature of illegitimate tasks, it is proposed that these tasks have the potential to affect employee engagement amongst primary school teachers in South Africa negatively. Therefore, to develop a better understanding of illegitimate tasks and the influence on employee well-being and behaviour, an indepth exploration of illegitimate tasks in the teaching profession in the South African context is required.

\section{Research methodology or strategy Research approach}

The study was guided by a qualitative research approach and was based on the assumptions of the interpretivist research paradigm, which holds the ontological position of relativism. This approach was adopted to gain insight into the lived experiences of teachers within their working environments (Scotland, 2012).

\section{Research strategy}

A cross-sectional qualitative research design guided the study. This entails the collection of data on a sample of cases at a single point in time and is used to elucidate, for example, the experience of a specific phenomenon. This design was useful in achieving the principles of the interpretivist paradigm by gaining insights into the phenomenon of illegitimate tasks as experienced by participating primary school teachers (i.e. relativism) (Bryman, 2016).

\section{Research method}

\section{Research setting}

The study was conducted amongst selected primary school teachers in the Metro Central Education District of the Department of Education, Western Cape Government. The selected schools were differentiated in terms of suburbs, socio-economic status and learner demographics.

\section{Entrée and establishing researcher roles}

Primary school teachers were recruited after obtaining approval from the Ethics Committee of the university where the study was undertaken and the Department of Education, Western Cape Government. The principal researcher established contact with the principals of the five participating primary schools with different socio-economic status, learner demographics and locations in the Metro Central Education District. 


\section{Research participants and sampling methods}

A non-probability purposive sampling approach yielded 10 primary school teachers $(n=10)$. All the teachers selected for this study met the selection criteria, that is they were employed on a permanent basis as primary school teachers with 2 years of formal teaching experience as a primary school teacher. Participation in the study by all participants was voluntary.

Two male and eight female participants were recruited, ranging from 25 to 55 years of age. Participant tenure in the educational sector ranged from 3 to 30 years. Participants taught Grade 1 to Grade 7 and taught various subjects including English First Language, Afrikaans Second Language, Life Skills, Art, Natural Sciences, Technology, Geography, History, Economic Sciences and Physical Education.

\section{Data collection methods}

Data were collected by the principal researcher through semi-structured interviews. This allowed for the formulation of additional questions, as judged appropriate, during interviews (Bless, Higson-Smith, \& Sithole, 2013). The interview guide (Appendix 1) was based on a review of relevant literature and was designed to meet the specific research objectives. The interviews took place at private locations (e.g. empty classrooms, staff rooms or offices) selected by the participants. Each interview lasted approximately $1 \mathrm{~h}$.

\section{Data recording}

The interviews were recorded electronically and transcribed verbatim by the primary researcher, as prescribed by Braun and Clarke (2013). During the transcription of interview recordings, participants' names were replaced with pseudonyms. Hard copies of documents were securely stored. Voice-recording and other electronic data documents were stored on a password-protected device and are only accessible to the researchers of the study.

\section{Strategies employed to ensure data quality and integrity}

To ensure the credibility of the findings, four types of data triangulation were applied at various stages of the study, namely data, theoretical, research and methodological triangulation (Abdalla, Oliveira, Azevedo, \& Gonzalez, 2018). Firstly, data triangulation was achieved by collecting data from different research participants from different schools. Secondly, theoretical triangulation was achieved by obtaining insights from other researchers with different theoretical perspectives to validate the methods used and findings obtained in the data collection and analysis phase of the study (i.e. consensus coding). Thirdly, researcher triangulation was achieved by making use of insights, perspectives and considerations of different researchers during the study, as well as member checking (Jonsen \& Jehn, 2009). Finally, methodological triangulation was achieved by combining data obtained from data collection with researcher field notes derived from observations made during individual interviews. These validating processes served to increase the rigor, diversity and depth of the research study.

\section{Data analysis}

The directed content analysis technique was applied to interpret, analyse and report the data. The goal of content analysis is 'to provide knowledge and understanding of the phenomenon under study' (p. 1278). This research method is widely used for the subjective interpretation of the content of text data. This is achieved by a systematic classification process which involves coding and the identification of themes or patterns (Hsieh \& Shannon, 2005).

Directed content analysis was deemed most appropriate for the purpose of the study as the goal of this approach is to conceptually validate or extend a theoretical framework or existing theory about a phenomenon that could benefit from further description. During this deductive category application, the researchers made use of theory of the construct of illegitimate tasks to focus the research objectives, compile the format of the interview guide and determine the initial coding scheme, based on the classification framework for illegitimate tasks (Hsieh \& Shannon, 2005).

To code the data, we began by identifying key concepts derived from existing theory to create initial coding categories, including unreasonable and unnecessary tasks, the environmental and psychological factors which contributed to the experience of illegitimate tasks and the outcomes of these tasks. After a process of data immersion, interview transcripts were read and all texts representing the various coding categories were highlighted. Thereafter, consensus coding (Abdalla et al., 2018) was conducted with a peer researcher to code all highlighted passages and texts into predetermined codes. Any text that could not be categorised by the initial coding scheme was identified and given a new code. Finally, through subsequent analysis, subcategories were created for existing codes pertaining to unreasonable and unnecessary tasks and outcomes of illegitimate tasks.

The findings were not only supported by theory but also provided supplementary evidence to extend the existing understanding of illegitimate tasks (Hsieh \& Shannon, 2005). The nine main codes and subcategories with accompanying exemplars and descriptive evidence are discussed in the subsequent section.

\section{Ethical considerations}

Ethical approval to conduct the study was obtained from the Department of Education, Western Cape Government (reference number: 20190403-3333) and the Research Ethics Committee: Humanities of Stellenbosch University (reference number: 9426).

\section{Results}

The main codes resulting from directed content analysis in the current study were: (1) illegitimate tasks which form part 
of the workload of teachers; (2) illegitimate tasks which fall outside of the scope of practice for teachers; (3) environmental factors which contribute to the experience of illegitimate tasks; (4) psychological factors contributing to the experience of illegitimate tasks; (5) emotional and/or psychological outcomes of illegitimate tasks; (6) physical outcomes of illegitimate tasks; (7) behavioural outcomes of illegitimate tasks; (8) the time-consuming nature of illegitimate tasks; and (9) mechanisms that buffer the effects of illegitimate tasks.

\section{Illegitimate tasks which form part of the workload of teachers}

An overarching finding of the study was that all of the participants experienced illegitimate tasks, to a greater or lesser extent, as part of their normal teaching workload. This theme is categorised into sub-themes, for either unnecessary or unreasonable tasks, including learner discipline, sport coaching, managerial duties, extra teaching duties and administrative duties.

\section{Learner discipline}

Maintaining regular learner discipline in a classroom environment is an important part of teaching. Some tasks relating to learner discipline were perceived as illegitimate tasks by participants, for example escorting learners to detention and resolving discipline incidents which occur at home:

'[An incident with a learner $]$... wasn't at school, it was something that happened at home ... and the parent brought it to me and wanted me to deal with it.' (Participant 10, teacher, female)

In general, participants expressed that constantly having to deal with learner discipline issues on a daily basis puts strain on them, as it takes valuable time away from teaching and can be exhausting.

\section{Sport coaching}

Sport coaching is often an essential requirement that teachers must perform. However, some participants regarded sport coaching as an illegitimate task, seeing that it could be done by persons who have more knowledge, expertise and passion for these types of tasks:

'Gee whiz, couldn't you get someone else to have done this ... certain sports ... could have been outsourced to a more expertise person.' (Participant 1, teacher, male)

\section{Managerial duties}

Managerial duties are generally assigned to teachers occupying higher-level positions. Some duties that teachers have to perform in a managerial role, including monitoring and reporting on colleagues' work (e.g. planning, classroom management, etc.), visits to colleagues' classrooms, disciplining colleagues and mediation between top management and lower-level colleagues, were regarded as illegitimate:

'When it comes to disciplining people, I'm not so good at that so I think it puts me in an awkward position to tell them ... they haven't done what they were supposed to do, so it puts you in an awkward position 'cause you're not the head of the school.' (Participant 5, teacher, female)

Some of these duties furthermore have the potential to impact interpersonal relationships in the workplace negatively.

\section{Extra teaching duties}

The extra teaching duties that were regarded as unnecessary tasks by participating teachers included marking, remedial teaching, meetings and workshops. Unreasonable extra teaching duties included teaching specific subjects and attending meetings. It can be argued that some of these duties form part of the core responsibilities of teachers but were experienced as unnecessary or unreasonable in accordance with the criteria of illegitimate tasks. The participants explained that heavy marking loads can be reduced or simplified and that remedial teaching duties could be done by individuals who are better equipped and trained to deal with the demands of this duty. Some participants felt that the attendance of some meetings and workshops should not have been done at all. Finally, the teaching of certain subjects was perceived by some participants to be an unreasonable duty:

'Being forced to teach certain subjects ... you often have to teach something because there's no one else to do it ... when you're being forced you don't have a passion in it.' (Participant 10, teacher, female)

Teachers receive specialised training in certain subjects and are sometimes required to teach subjects, which did not form part of their tertiary training.

\section{Administration}

Certain administrative duties were experienced as illegitimate tasks by the majority of the participants:

'I think they [management] need to re-shuffle their priorities and make the teachers more important instead of the admin and then things might change, 'cause admin is killing all the teachers, they hate it.' (Participant 2, teacher, female)

The unnecessary administrative duties experienced by participating teachers included doing photocopying work, Integrated Quality Management System (IQMS) execution, learner interventions and financial duties. The unreasonable administrative duties that teachers experienced emphasised financial duties, specifically:

'I don't think it's fair that I have to deal with like a lot of the admin things ... I don't think it's fair that I have to follow up in terms of ... money like finances ... as teachers we have enough on our plate and we shouldn't be dealing with like these extras.' (Participant 3, teacher, female)

\section{Illegitimate tasks which fall outside of the scope of practice for teachers}

Some participants experienced illegitimate tasks, to a greater or lesser extent, which they perceived to fall outside of the 
scope of practice for teachers. This included emotional support, fundraising, maintenance duties and charity duties.

\section{Emotional support}

Although emotional support for learners might be considered a sub-task of teaching, some participants felt that these tasks fit the criteria of illegitimate tasks. Participants explained that the counselling nature of providing emotional support for learners in different scenarios, sometimes put them in an awkward position, was emotionally exhausting, and could be very time: 'I was not trained to be a counsellor.' (Participant 1 , teacher, male)

\section{Fundraising}

Fundraising duties were regarded by most participants as illegitimate tasks that fall outside of the scope of practice for teachers. These duties are extensive in nature and include work experiences such as:

\footnotetext{
"'It becomes almost your problem, your airtime, your pockets, your riding around collecting things, picking up things ..." (Participant 5, educator, female), and "... having to deal with the complete set-up and takedown [of stalls] and preparation and typing of letters to parents and ... distributions ...".' (Participant 3 , teacher, female)
}

Many participants explained that they felt strongly that other stakeholders should be responsible for fundraising initiatives at their respective schools.

\section{Maintenance and charity duties}

General duties associated with the maintenance of school grounds and buildings could arguably fall outside of the scope of practice associated with teaching, as illustrated in the following excerpt:

'I think with like the maintenance ... I don't know anything about buildings as such ... I don't know anything about electricity and ... gardening and so on.' (Participant 5 , teacher, female)

Furthermore, it could be argued that charitable duties, such as providing learners with stationery and clothing, bought by teachers with their own money, fall outside of the scope of practice of teachers:

'I've had situations ... where I was expected to buy clothes for the child, like what happens, if they don't have something I make sure they get it ... where stationery is concerned.' (Participant 6, teacher, female)

\section{Environmental factors contributing to the experience of illegitimate tasks}

A third theme of the study illustrates participants' perceptions regarding the environmental factors which contributed to their experience of illegitimate tasks. Sub-themes of the environmental factors which contributed to the experience of illegitimate tasks included organisational structure and functioning, curriculum demands, lack of resources, learner characteristics and parental support.
Firstly, the findings indicate that the allocation of duties by school management, for example teachers not involved in the decision-making process, 'when you get given tasks that you weren't part of the decision-making in the first place, so why is this coming to you?' (Participant 3, teacher, female), school leadership, 'I think leadership is the main one ... just a lack of anyone taking authority' (Participant 3, teacher, female) and workplace culture, "“the educators" ... lack of responsibility, you now having to pick up other people's slack, because they don't see the school holistically' (Participant 6, teacher, female), formed part of organisational structure and functioning, which contributed to their experience of illegitimate tasks.

Secondly, some participants explained that their experience of illegitimate tasks is influenced by the demands placed on them by the curriculum, specifically the National Curriculum Assessment Policy Statements (CAPS), as provided by the National Curriculum Statement of the DBE (2019). Thirdly, a lack of physical resources (e.g. teaching materials and supplies) caused some of the participants to present lessons 'from scratch', prepare and execute lessons and assessments without the necessary resources and personally fund the needed resources to execute some lessons.

Fourthly, some participants explained that their experience of illegitimate tasks was based on diverse learner characteristics, such as learner discipline, providing emotional support to learners and extra teaching duties (e.g. remedial teaching). Finally, the experience of illegitimate tasks was because of lower levels of parental support:

'You sometimes don't get any cooperation from the parents ... I'm the educator and if the mom or the dad can't bring [the learner] in line, what hope do I have?' (Participant 1, teacher, male)

\section{Psychological factors contributing to the experience of illegitimate tasks}

The influential psychological factors which contributed to the experience of illegitimate tasks amongst participants consist of four related sub-themes.

Firstly, some teachers' inability to voice their opinions regarding the tasks which they had to perform on a day-today basis caused the experience of illegitimate:

'You cannot turn to your boss or principal or anyone and say ... "That's not part of my scope of work" ... you can't do that.' (Participant 3, teacher, female)

Secondly, participants' beliefs regarding the decreased standards of educators, 'I think that the standards of educators in a whole has dropped.' (Participant 6, teacher, female), as well as their religious beliefs, 'Being a Christian ... I feel that I do things because this is not just a job.' (Participant 7, teacher, male), and thirdly, personality characteristics, 'I think my personality is such that I believe in leading by example' (Participant 4, teacher, female), contributed to participants' experience and execution of illegitimate tasks. Finally, a perception of an obligation to 
execute tasks was considered a contributing factor to the experience of illegitimate tasks, 'I'm very respectful of people that's in authority, so if it's expected or asked, then I would do it ... because someone in authority almost demands it from me' (Participant 5, teacher, female).

\section{Psychological and emotional outcomes of illegitimate tasks}

The psychological outcomes identified because of the experience of illegitimate tasks identified by teachers included decreased job satisfaction, withdrawal intentions (e.g. increased sick-leave and intention to quit), feeling demotivated and despondent and a decrease in professional efficacy. One participant expressed the following feelings towards teaching as an occupation:

'There's so much red tape that a teacher has to jump over and work themselves through ... it's just not worth it, it's not worth it at the end of the day ... and you're just fighting what seems to be a losing battle.' (Participant 3 , teacher, female)

Participants experienced negative emotional states because of illegitimate tasks. This included negative emotional affects, 'it does affect you ... just negatively in terms of your feelings' (Participant 3, teacher, female), anxiety and stress, 'so that's very awkward, it's very uncomfortable, it nags on you, it worries you' (Participant 1, teacher, male), feeling discomfort, frustration and anger, 'those things really annoy me ... I mean that makes you so angry as a teacher' (Participant 9, teacher, male).

\section{Physical outcomes of illegitimate tasks}

The sixth finding focusses on the physical outcomes of illegitimate tasks. Some of the participants expressed negative physical outcomes because of their experience of illegitimate tasks within the teaching profession, which included physical illness, 'I physically get sick ... I landed up in hospital' (Participant 6, teacher, female), exhaustion, 'I suppose all of these things [illegitimate tasks], like I said, are very, very draining' (Participant 10, teacher, female), fatigue, 'but you're in bed by eight o'clock ... your life is not normal ... I'm constantly tired' (Participant 3, teacher, female) and insomnia.

\section{Behavioural outcomes of illegitimate tasks}

The seventh finding of the study illustrates two sub-themes of behavioural outcomes as a result of illegitimate tasks. The first entails behavioural outcomes at home, where participants explained that they tend to neglect their home duties, experience a negative impact on their interpersonal relationships, 'It does spill over, sometimes you take it out on the people at home' (Participant 5, teacher, female), impatience, 'I often find that I would get home and I would have no patience left at home to deal with [issues]' (Participant 4, teacher, female) and demotivation, 'I go home feeling deflated, I feel demotivated' (Participant 3, teacher, female), as well as increased alcohol use.
Secondly, behavioural outcomes at work, where the experience of illegitimate tasks has a negative impact on teachers' interpersonal relationships at work, 'There's heaviness, there's tension between adults [colleagues]' (Participant 1, teacher, male), negative behaviour towards learners, '... on my children [learners], you know, I get frustrated and take it out on them' (Participant 9, teacher, female) and the experience of emotional overload, 'I actually have to go to the bathroom [at work] because I couldn't hold it together anymore' (Participant 10, teacher, female).

\section{The time-consuming nature of illegitimate tasks}

Participants emphasised the burden that illegitimate tasks place on them, specifically the time that they take to execute these tasks. They expressed that these tasks impact their workload and time management as they detract from more constructive teaching activities and core duties associated with teaching, 'I don't have enough time in the day to do everything that is expected' (Participant 10, teacher, female). The time-consuming nature of illegitimate tasks was additionally found to be associated with various administrative duties, remedial teaching, learner discipline, financial duties, fundraising, managerial duties and sport coaching.

\section{Mechanisms that buffer the effects of illegitimate tasks}

The findings of the study shed light on different mechanisms (e.g. attitudes, beliefs, perceptions, environmental factors, etc.), which have the potential to buffer the negative effects of illegitimate tasks. These mechanisms included a sense of calling and working with children, 'Ja, I can keep myself going, but you know I said: "As long as I'm still touching some of these little hearts I will continue ..."' (Participant 4, teacher, female), maintaining a work-life balance, 'On weekends I do nothing related to school, I just switch off completely' (Participant 8, teacher, male), voicing of opinion, 'I would say: "No, I'm not going to do that"' (Participant 2, teacher, female), organisational commitment, 'I feel I am very passionate about this school' (Participant 6, teacher, female) and the perception of a learning experience or developmental opportunity, 'You constantly need to push yourself and deal with what comes your way ... for yourself you know, for personal growth reasons' (Participant 9, teacher, female). More than half of the participants expressed these mechanisms that they experienced.

\section{Summary of results}

In summary, the results of the study (Figure 1) indicated that certain environmental and psychological factors contributed to the experience of illegitimate tasks amongst participating primary school teachers. These factors lead to the experience of illegitimate tasks (i.e. unnecessary or unreasonable), either forming part of the workload of teachers or falling outside of the scope of practice of teachers. Illegitimate tasks were additionally considered to be time consuming in nature. The experience of illegitimate tasks led to emotional, psychological, 


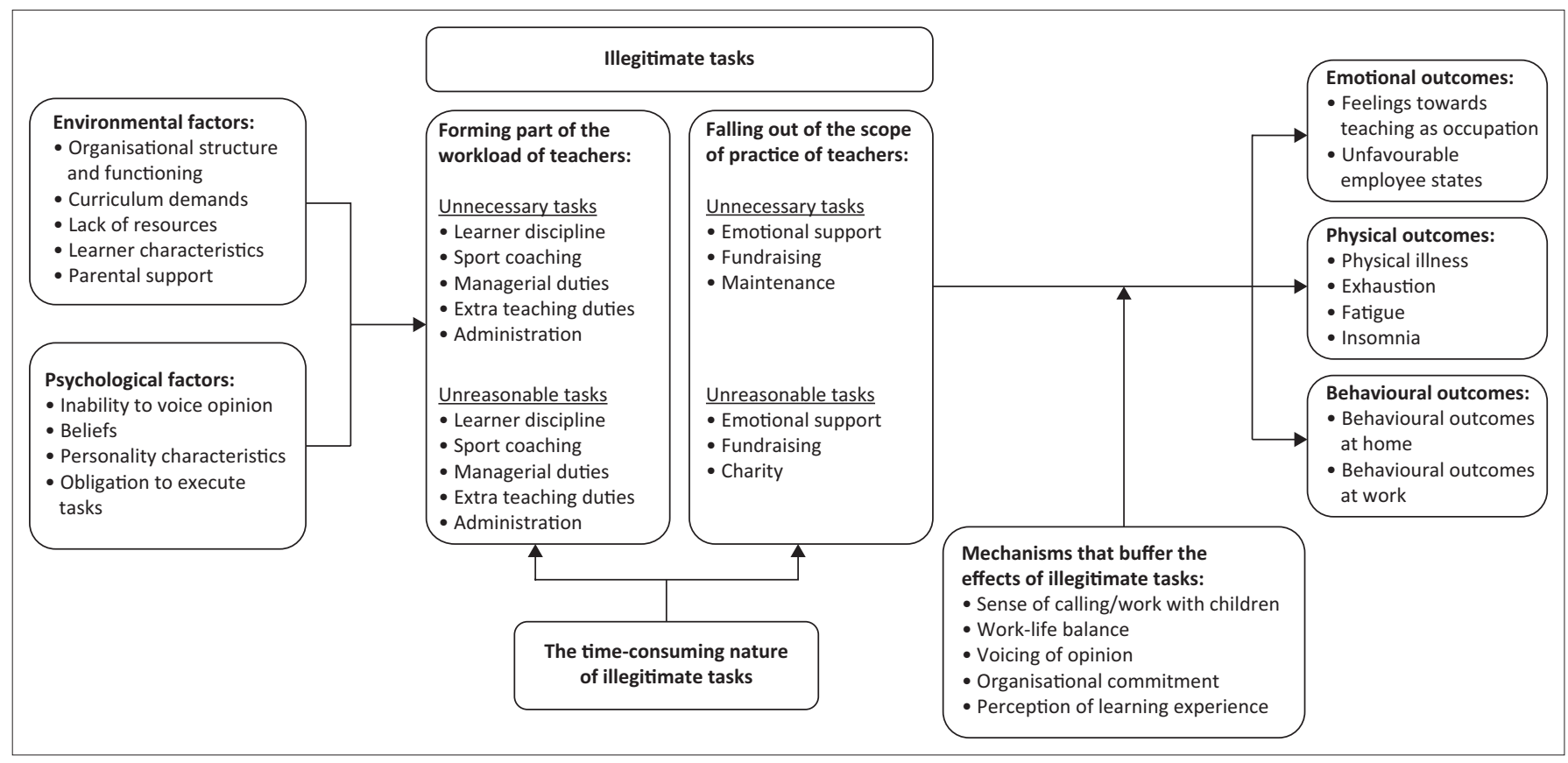

FIGURE 1: A proposed framework of illegitimate tasks derived from the findings of the study.

physical and behavioural outcomes. Finally, specific mechanisms that acted as buffers resulting in reduced negative effects of illegitimate tasks on teachers were identified.

\section{Discussion}

The primary aim of this article was to examine the work experiences, specifically illegitimate tasks, of primary school teachers at selected schools in the Western Cape. The main findings of the study provided valuable insights into the constructs of illegitimate tasks, as experienced by participants, including: (1) the perceived experience of illegitimate tasks amongst primary school teachers, (2) the perceived environmental and psychological factors contributing to the experience of illegitimate tasks, (3) the psychological, emotional, physical and behavioural outcomes of illegitimate tasks, (4) the time-consuming nature of illegitimate tasks and (5) the mechanisms that could provide potential buffers to the effects of illegitimate tasks.

\section{Outline of the results}

\section{The perceived experience of illegitimate tasks amongst primary school teachers}

Illegitimate tasks that form part of the workload of teachers (i.e. learner discipline, sport coaching, managerial duties, extra teaching duties and administrative duties) and that fall outside of the scope of practice for teachers (i.e. emotional support [for learners], fundraising, maintenance and charity work), could generally be conceived as tasks that form part of the normal role of the teacher within the normal functioning of a school and the imperatives of the South African basic educational system. However, the findings of this study highlighted the fact that the participating teachers did experience some aspects of their normal workload to be unnecessary and/or unreasonable and beyond their scope of practice. These tasks were regarded as tasks which could be annoying to deal with at times and were not regarded as core tasks of teaching or contributors to teachers' professional identity (Jacobshagen, 2006).

\section{The perceived environmental and psychological factors contributing to the experience of illegitimate tasks}

The findings of the study indicated numerous environmental factors that contributed to the teachers' experience of illegitimate tasks (i.e. organisational structure and functioning, curriculum demands, lack of resources, specific learner characteristics and parental support). Demerouti and Bakker (2011) explain that job demands comprise the physical, psychological, social or organisational aspects of a job. These demands are associated with certain physiological and psychological costs, which result in physical, mental or psychological effort from employees.

Hence, the aforementioned environmental factors can be classified as organisationally based job demands, with the exception of specific learner characteristics and parental support, which can be regarded as social job demands. The psychological factors which contributed to the teachers' experience of illegitimate tasks (i.e. the inability to voice an opinion, beliefs, personality characteristics and obligation to execute tasks) could be regarded as psychological job demands experienced by teachers (Demerouti \& Bakker, 2011). These findings are aligned with the job demands of the JD-R model.

\section{The emotional, psychological, physical and behavioural outcomes of illegitimate tasks}

Various authors have argued that the experience of illegitimate tasks can lead to outcomes, which could negatively affect employees' health and behaviour (Eatough et al., 2016), various unfavourable employee states at the 
end of the workday and a detachment from work (Sonnentag \& Lischetzke, 2018), intention to quit because of poor workrole fit (Janik \& Rothman, 2015), turnover intention (Apostel et al, 2018) and work stress (Milner \& Khosa, 2008; Semmer et al., 2015).

The findings of this study shed light on the psychological, emotional, physical and behavioural outcomes of illegitimate tasks. In contrast to previous studies (Eatough et al., 2016; Semmer et al., 2015), these findings provided additional insights into the outcomes of illegitimate tasks, which included feeling demotivated and despondent, negative emotional affects, feeling uncomfortable, experiencing frustration, exhaustion, fatigue and insomnia and various negative behavioural outcomes at home and at work.

Based on the extensive outcomes of illegitimate tasks on participants in this study, one could deduce that illegitimate tasks, as a high-level hindrance job demand, activated the health impairment process of the participating teachers (Demerouti \& Bakker, 2011; Saks \& Gruman, 2014). To illustrate, the exhaustion of teachers' physical and mental resources resulted in negative feelings towards the teaching occupation, unfavourable employee states, health problems and negative behavioural outcomes, which could be associated with job burnout (Hakanen, Bakker, \& Schaufeli, 2006) and disengagement. This is once again supported by the tenets of the JD-R model (Demerouti \& Bakker, 2011; Saks \& Gruman, 2014).

\section{The time-consuming nature of illegitimate tasks}

The findings indicated that illegitimate tasks were perceived to be time consuming in nature. Similar findings could not be allocated in literature and the perception of time is also not included in the definition, but could be implied. The teachers generally expressed negative perceptions regarding the amount of time it took to execute illegitimate tasks and indicated that illegitimate tasks took them away from more important teaching duties or activities.

Peltzer, Shisana, Zuma, Van Wyk and Zungu-Dirwayi (2009) reported that the high stress levels of South African teachers were because of the sources of job stress, one of which focussed on time pressures. Teachers, in general, experience high levels of time pressures in their occupation. It could thus be argued that the time-consuming nature of illegitimate tasks places additional demands on them that may further influence job stress.

\section{Mechanisms providing potential buffers to the effects of illegitimate tasks}

In contrast to other studies (Eatough et al., 2016; Semmer et al., 2015; Sonnentag \& Lischetzke, 2018), the findings of this study shed light on the mechanisms that provided buffers to the potential negative effects of illegitimate tasks in the teaching profession. Some of the teachers explained that although they sometimes have to execute what they regard as illegitimate tasks, they draw on the aid of various mechanisms to assist them in coping with the demands of illegitimate tasks. These mechanisms consisted of a sense of calling and working with children, maintaining a work-life balance, voicing of opinions, organisational commitment and the perception of illegitimate tasks, providing a learning experience or developmental opportunity.

These findings correlate with the main premise of positive psychology. That is, to generate a balanced and complete scientific understanding of human experiences, a comprehensive understanding of suffering and happiness is required (Seligman \& Steen, 2005). The above-mentioned mechanisms could be regarded as a concept, which increases the happiness of teachers.

Within the framework of the JD-R, these mechanisms could be regarded as job resources (e.g. a sense of calling, task significance, voicing of opinions and learning and developmental opportunities) or personal resources (e.g. a work-life balance, voicing of opinions and organisational commitment), which buffer the negative effects of illegitimate tasks (i.e. job demands) and are therefore functional in achieving work goals and increased levels of employee engagement. They additionally stimulate learning, development and personal growth. Job or personal resources are located on an organisational and social level or within a job position or the task itself (Demerouti \& Bakker, 2011; Saks \& Gruman, 2014).

\section{Practical implications}

Various stakeholders in the education system in South Africa (i.e. the Department of Education, educational unions, school governing bodies and management teams and teachers, amongst others) could benefit from the following considerations regarding illegitimate tasks within primary schools. Firstly, the identification of illegitimate tasks could lead to the development of relevant interventions, which can be used to reduce the associated negative experience amongst primary school teachers.

Secondly, interventions aimed at addressing the environmental and psychological factors, which contribute to the experience of illegitimate tasks, could be developed and implemented. Examples include a review of the structural and functional aspects of schools, the functionality of leadership and workplace culture, reducing the constraints placed on teachers regarding curriculum demands and lack of resources, teacher training and support programmes to enhance coping with diverse learner demands and differing levels of parental support.

Thirdly, interventions focussing on the emotional, psychological, physical and behavioural outcomes of illegitimate tasks could be implemented. These interventions should be aimed at mitigating the burdensome experiences associated with illegitimate tasks, as well as providing initiatives (e.g. employee wellness programmes) aimed at reducing and recovery from the negative effects of illegitimate tasks (Sieberhagen, Pienaar, \& Els, 2011). 
Finally, strong emphasis should be placed on the mechanisms that buffer the effects of illegitimate tasks amongst primary school teachers. Possible interventions could focus on developing teachers' sense of calling (Fouche, Rothmann, \& Van der Vyver, 2017), acknowledging and showing appreciation for the value added by teachers' work, increasing teachers' levels of organisational commitment (Geldenhuys, Laba, \& Venter, 2014; Lumley, Coetzee, Tladinyane, \& Ferreira, 2011), providing guidance on maintaining a work-life balance (Haar, Russo, Sune, \& Ollier-Malaterre, 2014) and creating a working environment where teachers have the freedom to voice their opinions regarding task execution.

\section{Limitations and recommendations}

The study was conducted with participating teachers from selected primary schools in a selected education district. Although it would have been valuable to conduct the study amongst primary school teachers from other education districts and provinces in South Africa, this would not have been feasible because of time and financial constraints. The findings of the study may have relevance in similar contexts, which should be gauged by the reader. Because of ethical considerations and the small sample of participants, the researchers were not allowed to elaborate on the socioeconomic stance of any of the participating schools or any specific identifying criteria for participants (e.g. grades and subjects taught). The researchers acknowledge that this information could have added to the richness of the findings of the study.

In terms of future research initiatives, firstly, it is recommended that the study be duplicated amongst primary and secondary school teachers from other education districts and provinces within the country. Specific attention can also be given to the differentiation between illegitimate tasks experienced amongst schools from differing socio-economic statuses, learner demographics, grades and subjects taught by teachers, etc. This could aid in expanding the understanding of illegitimate tasks experienced by teachers. Secondly, it is recommended that the study be replicated amongst school management and leadership teams to gain a more systematic conceptualisation of the construct of illegitimate tasks in the education system. Thirdly, the researchers are confident that the findings obtained by the study will lay the foundation for quantitative studies regarding this emerging research area. It is recommended that future research studies focus on empirically validating the findings of this study. The themes could inform structural models that empirically evaluate the experience of illegitimate tasks in the education system in South Africa. Finally, future research studies could focus on developing and evaluating interventions aimed at addressing the challenges experienced because of illegitimate tasks amongst public school teachers.

\section{Conclusion}

This article makes a valuable contribution to the identification, understanding and potential mitigation of illegitimate tasks within the selected schools in the Western Cape. A comprehensive understanding of illegitimate tasks in this context, could, in turn, potentially lead to the improvement of the work experiences of teachers. We argue that an engaged and motivated teacher will be more likely to motivate and inspire learning, enhancement and progress in their learners. By focussing on the improvement of primary school teachers' work experiences, as opposed to focussing on learner needs in an isolated manner, the general success of the educational system and the standard of basic education in the country could potentially be influenced dramatically.

\section{Acknowledgements}

The authors would like to acknowledge the support of the Department of Education, Western Cape Government and the participating primary school teachers.

\section{Competing interests}

The authors declare that they have no financial or personal relationships that may have inappropriately influenced them in writing this research article.

\section{Authors' contributions}

The study was conceptualised by Z.v.N. and S.G. Z.v.N. conducted and coordinated the data collection, analysis and interpretation. Z.v.N., S.G. and S.P.A. were co-authors of the manuscript. S.G. was the study leader of the project.

\section{Funding information}

This research received no specific grant from any funding agency in the public, commercial or not-for-profit sectors.

\section{Data availability}

The data that support the findings of this study are available from the corresponding author, Z.v.N., upon reasonable request.

\section{Disclaimer}

The views and opinions expressed in this article are those of the authors and do not necessarily reflect the official policy or position of any affiliated agency of the authors.

\section{References}

Abdalla, M.M., Oliveira, L.G., Azevdo, C.E.F., \& Gonzalez, R.K. (2018). Quality in qualitative organisational research: Types of triangulation as a methodological alternative. Administracao: Ensino E Pesquisa, 19(1), 66-98. https://doi. org/10.13058/raep.2018.v19n1.578

Apostel, E., Syrek, C.J., \& Antoni, C.H. (2018). Turnover intention as a response to illegitimate tasks: The moderating role of appreciative leadership. International Journal of Stress Management, 25(3), 234-249. https://doi.org/10.1037/ str0000061

Björk, L., Bejerot, E., Jacobshagen, N., \& Härenstam, A. (2013). I shouldn't have to do this: Illegitimate tasks as a stressor in relation to organizational control and resource deficits. Work \& Stress, 27(3), 262-277. https://doi.org/10.1080/026783 73.2013 .818291

Bless, C., Higson-Smith, C., \& Sithole, S.L. (2013). Fundamentals of social research methods: An African perspective (5th edn.). Lusaka: Juta \& Company Ltd. 
Braun, V., \& Clarke, V. (2013). Successful qualitative research: A practical guide for beginners. London: Sage.

Bryman, A. (2016). Social research methods. Oxford: Oxford University Press.

Demerouti, E., \& Bakker, A.B. (2011). The Job Demands-Resources model: Challenge for future research. Journal of Industrial Psychology/SA Tydskrif vir Bedryfsielkunde, 37(2), 1-9. https://doi.org/10.4102/sajip.v37i2.974

Demerouti, E., Bakker, A.B., Nachreiner, F., \& Schaufeli, W.B. (2001). The job demandsresources model of burnout. Journal of Applied Psychology, 86(3), 499-512. https://doi.org/10.1037/0021-9010.86.3.499

Department of Basic Education (DBE). (2009). Education statistics in South Africa 2007. Pretoria: Department of Education. Retrieved from http://www.dhet gov. za/PSET\%20Statistics/DoE\%20Stats\%20at\%20a\%20Glance\%202007.pdf

Department of Basic Education (DBE). (2010). Education statistics in South Africa 2008. Pretoria: Department of Education. Retrieved from http://www.dhet.gov. za/DHET\%20Statistics\%20Publication/DoE\%20Stats\%20at $\% 20$ a \% 20 Glance $\% 20$ 2008.pdf

Department of Basic Education (DBE). (2019). Report on the National Senior Certificate examination. Pretoria: Department of Education. Retrieved from https://www. education.gov.za/Portals/0/Documents/Reports/NSC\%202018\%20 Examination\%20Report\%20WEB.pdf?ver=2019-01-03-085338-000

Department of Basic Education (DBE). (2020). Report on the National Senior Certificate examination. Pretoria: Department of Education. Retrieved from https://www.
education.gov.za/Portals/0/Documents/Reports/2019\%20NSC\%20 Examination\%20Report.pdf?ver=2020-01-07-155811-230

Eatough, E.M., Meier, L.L., Igig, I., Elfering, A., Spector, P.E., \& Semmer, N.K. (2016). You want me to do what? Two daily diary studies of illegitimate tasks and employee well-being. Journal of Organisational Behaviour, 37, 108-127. https://doi. org/10.1002/job.2032

Fouche, E., Rothmann, S., \& Van der Vyver, C. (2017). Antecedents and outcomes of meaningful work among school teachers. SA Journal of Industrial Psychology/SA Tydskrif vir Bedryfsielkunde, 43(0), 1-10. https://doi.org/10.4102/sajip.v43i0. 1398

Geldenhuys, M., Laba, K., \& Venter, C.M. (2014). Meaningful work, work engagement and organisational commitment. SA Journal of Industrial Psychology/SA Tydskrif vir Bedryfsielkunde, 40(1), Art. \#1098, 10 pages. http://doi.org/10.4102/sajip. v40i1.1098

Haar, J.M., Russo, M., Sune, A., \& Ollier-Malaterre, A. (2014). Outcomes of work-life balance on job satisfaction, life satisfaction and mental health: A study across seven cultures. Journal of Vocational Behaviour, 85(2014), 361-373. https://doi. org/10.1016/j.jvb.2014.08.010

Hakanen, J.J., Bakker, A.B., \& Schaufeli, W.B. (2006). Burnout and work engagement among teachers. Journal of School Psychology, 43, 495-513. https://doi. org/10.1016/j.jsp.2005.11.001

Hofmeyr, J., \& Draper, K. (2015). Technical report: Teacher supply and demand in South Africa: 2013 to 2025. Centre for Development and Enterprise. Retrieved from http://www.sablenetwork.com/pdf/TeacherSupplyandDemand2025.pdf

Hsieh, H., \& Shannon, S.E. (2005). Three approaches to qualitative content analysis Qualitative Health Research, 15(9), 1277-1288. https://doi.org/10.1177/ 1049732305276687

Jacobshagen, N. (2006). Illegitimate tasks, illegitimate stressors: Testing a new stressor-strain concept. Unpublished Master's thesis. Bern: University of Bern.
Janik, M. \& Rothmann, S. (2015). Meaningful work and secondary school teachers' intention to leave. South African Journal of Education, 35(2), 1-13. https://doi. org/10.15700/saje.v35n2a1008

Jonsen, K., \& Jehn, K.A. (2009). Using triangulation to validate themes in qualitative studies. Qualitative Research in Organisations and Management: An International Journal, 4(2), 123-150. https://doi.org/10.1108/17465640910978391

Lumley, E.J., Coetzee, M., Tladinyane, R., \& Ferreira, N. (2011). Exploring the job satisfaction and organisational commitment of employees in the information technology environment. Southern African Business Review, 15(1), 100-118.

Mampane, P.M. (2012). The teacher turnover crisis. Evidence from South Africa. Business Education \& Accreditation, 4(2), 73-83.

Milner, K., \& Khosa, H. (2008). A comparison of teacher stress and school climate across schools with different matric success rates. South African Journal of Education, 28, 155-173. https://doi.org/10.15700/saje.v28n2a38

Modisaotsile, B.M. (2012). The failing standard of basic education in South Africa. Africa Institute of South Africa: Policy Brief, 72, 1-8.

Peltzer, K., Shisana, O., Zuma, K., Van Wyk, B., \& Zungu-Dirwayi, N. (2009). Job stress, job satisfaction and stress-related illness among South African educators. Stress and Health, 25, 247-257. https://doi.org/10.1002/smi.1244

Saks, A.M., \& Gruman, J.A. (2014). What do we really know about employee engagement? Human Resource Development Quarterly, 25(2), 155-182. https:// doi.org/10.1002/hrdq.21187

Scotland, J. (2012). Exploring the philosophical underpinnings of research: Relating ontology and epistemology to the methodology and methods of the scientific, interpretive, and critical research paradigms. English Language Teaching, 5(9), 9-16. https://doi.org/10.5539/elt.v5n9p9

Scriven, M. (1994). Duties of the teacher. Journal of Personnel Evaluation in Education, 8(2), 1-30. https://doi.org/10.1007/BF00972261

Seligman, M.E.P., \& Steen, T.A. (2005). Positive psychology progress: Empirical validations of interventions. The American Psychological Association, 60(5), 410-421. https://doi.org/10.1037/0003-066X.60.5.410

Semmer, N.K., Jacobshagen, N., Meier, L.L., Elfering, A., Beehr, T.A., Kälin, W., \& Tschan, F (2015). Illegitimate tasks as a source of work stress. Work \& Stress, 29(1), 32-56. https://doi.org/10.1080/02678373.2014.1003996

Sieberhagen, C., Pienaar, J., \& Els, C. (2011). Management of employee wellness in South Africa: Employer, service provider and union perspectives. South African Journal of Human Resource Management/Suid-Afrikaanse Tydskrif vir Menslikehulpbronbestuur, 9(1), Art. \#305, 14 pages. https://doi.org/10.4102/ Menslikehulpbron
sajhrm.v9i1.305

Sonnentag, S., \& Lischetzke, T. (2018). Illegitimate tasks reach into afterwork hours: A multilevel study. Journal of Occupational Health Psychology, 23(2), 248-261. https://doi.org/10.1037/ocp0000077

Spaull, N. (2013). South Africa's education crisis: The quality of education in South Africa 1994-2011. Johannesburg: Centre for Development and Enterprise.

Taylor, N. (2008). What's wrong with South African schools? What's working in school development? Johannesburg: Jet Education Services.

World Economic Forum. (2018). The global competitiveness report 2017-2018 Retrieved from http://www3.weforum.org/docs/GCR2017-2018/05FullReport/ TheGlobalCompetitivenessReport2017\%E2\%80\%932018.pdf 


\section{Appendix 1: Interview guide Biographic information:}

1. Pseudonym

2. Age

3. Gender

4. Highest level of education (Bachelor's degree, Post-graduate Diploma, other)

5. Job title

6. Tenure (years and months)

7. Subjects taught

8. Grades taught

\section{General questions:}

1. Are you aware of the Department of Basic Education's official framework of job descriptions for teachers?

2. What do you view as the most important duty of a teacher?

\section{Work tasks experienced:}

1. Please list/name the duties/tasks that you have to perform on a daily, weekly or monthly basis in terms of the following areas/facets of the school:

\begin{tabular}{|l|l|l|}
\hline Classroom & Playground & Sport \\
\hline Culture & Meetings & Training \\
\hline Administration & Parents & Transportation \\
\hline Travel & After hours & Entertainment \\
\hline Fundraising & Maintenance & Counselling \\
\hline Decorating & Catering & Medical support/first aid \\
\hline Health and safety & Aftercare & Supervision \\
\hline Leave (preparation and supervision) & Curricular/academic & Other \\
\hline
\end{tabular}

2. Do you have work tasks to take care of which you already mentioned or cross your mind now which kept you wondering if:
a) they have to be done at all?
b) they could have been done by someone else?
c) they would not be done at all if re-organisation of work would take place?
d) they could be done with less effort if the re-organisation of work would take place?
e) they just exist because of a special orientation towards certain people?

Additional question:

Do situations at work exist which triggers thoughts like 'This is not necessary' or 'Why do I have to do this? What kind of situation or tasks triggers these thoughts?'

3. Do you have work tasks to take care of which you already mentioned or cross your mind now which you believe:
a) should be done by someone else?
b) should not be expected from you, which are reaching too far?
c) put you into an awkward position?
d) are not tasks you should be bothered with?
e) are not fair that you have to deal with them?

\section{Contributors to the perception of illegitimate tasks}

1. Which environmental factors contribute to your experience of the above-mentioned tasks?

2. Which psychological factors (or feelings) contribute to your experience of the above-mentioned tasks?

3. What outcomes do these tasks have on you emotionally/psychologically?

4. What outcomes do these tasks have on your behaviours at work/home? 